\title{
Russia's Post-Soviet Ideological Terrain: Zvyagintsev's Leviathan and Debates on Authority, Agency, and Authenticity
}

\author{
Susanne Wengle, Christy Monet and Evgenia Olimpieva
}

\section{Ideology in Putin's Russia}

How can we understand the ideological terrain in contemporary Russia? Much of the literature on post-Soviet ideology works with relatively narrow interpretations of ideology as the content of elite and state-sponsored doctrines. Research in this vein has examined the increasingly prominent role of the Kremlin in shaping media and cultural content under Putin-in particular, the circulation of ubiquitous narratives that stress the competence of the state, the sanctity of the church, the principles of patriotism and nationalism, and depictions of the west as hostile. ${ }^{1}$ Other studies have focused on trends in public opinion, which state-sponsored discourse taps into and tries to manipulate. ${ }^{2}$ Yet, what is unclear and merits discussion is the way in which state-sponsored perspectives and societal voices interact and how these interactions shape Russia's ideological terrain. This paper seeks to chart post-Soviet ideology not as state-sponsored propaganda or public opinion trends, but as a dialogue between myriad state and societal voices.

The paper's main goal is to provide an original, multi-dimensional, and reflexive account of Russia's ideological terrain, as informed by a dialogic definition of ideology. To chart the post-Soviet ideational landscape in this way, we turn to Putin-era cultural production and the remarkably critical voices within it-specifically, to Andrey Zvyagintsev's film Leviathan (2014) and the public debates it triggered. The plot of Leviathan revolves around the family and home of Nikolai "Kolya” Sergeiev (played by Alexei Serebryakov), a middle-aged, re-married father and car mechanic whose ancestral home is taken over by the small fishing town's corrupt Mayor Vadim (Roman Madyanov). Kolya, his wife Lilya (Elena Lyadova), and his old friend and lawyer Dima (Vladimir Vdovichenkov) begin the film united as the powerless against the powerful. They fight to keep Kolya's ancestral home from expropriation by the town's authorities-representatives of the eponymous "Leviathan"-only to fall incredibly low. In the end, Dima barely survives the confrontation with state power, Lilya dies, and Kolya is incarcerated.

1. Scholars such as Marlene Laruelle, Marina Peunova, Peter Rutland, and Elena Chebankova have provided excellent studies of ideational trends-from Eurasianism to conservative modernization-circulating among Russia's elite, including policymakers, policy backers, and regime ideologues; Laruelle (2017) has recently called this "the Kremlin's ideological ecosystems." See “Ideology in Contemporary Russia” section below.

2. Alexander Lukin and Peter Kolesnikov account for the ways in which elite ideational thinking responds to historically stable sets of demands from society. See the section "Ideology in Contemporary Russia" below. 
Leviathan was, in many ways, an exceptional film, not least of all because it was a critical social voice that resonated widely with diverse audiences across Russia. Released in 450 theaters across Russia in February 2015, it was widely seen and stirred vivid public controversy-a debate the kind of which the country had not seen since the 2011-12 protests. ${ }^{3}$ Although Zvyagintsev at times shied away from calling his work a political film, Leviathan elicited critical, powerfully argued responses from many of Russia's everyday citizens and most prominent public intellectuals alike, whose commentary on the film exploited vulnerabilities in the dominant political narratives of the Putin era. ${ }^{4}$ Much lively discussion of Leviathan took place on social media: the Russian blogosphere mentioned the film over 8000 times within a year of its release. ${ }^{5}$ Leviathan has continued to generate public commentary since. Hash tag Leviathan (\#Левиафан) is frequently used by Russian twitter users who are outraged by unacceptable, absurd, or even cruel and inhuman state actions. In 2015, Alexei Naval'nyi, Russia's most prominent opposition leader, started the online media project leviathan.fbk.info, which collects ordinary Russians' experiences that are reminiscent of the movie. In Naval'nyi's words, Leviathan.fbk.info is an "infinite feed of absurd, insane, cynical and inexplicable facts, citations, numbers and images," which, when shared with friends, should prompt Russians to "rethink their attitude towards the mess, absurdity and cynicism that today constitute the socio-political life of our country." 6

What, then, can we learn about post-Soviet ideology from Zvyagintsev's film and the public debates that followed its release? We argue that at least three important public debates merit attention as constitutive features of Russia's contemporary ideological terrain and play a role in the country's

3. Before its release, it was downloaded and viewed by an estimated 4 million viewers. As reported by Russia's News Agency TASS, “Leviafan v internete posmotreli okolo 4 mln zritelei," at https://tass.ru/kultura/1728689 (last accessed September 25, 2018). Vlad Strukov, a prominent Russian film scholar notes: "Arguably, between December 2014 and January 2015, Leviathan and the political controversy around it became the most discussed culture-related topic in RF since Russia's independence in 1991.” Vlad Strukov, "Russian 'Manipulative Smart Power': Zviagintsev's Oscar Nomination, (Non-)government Agency and Contradictions of the Globalized World," New Cinemas: Journal of Contemporary Film 14, no. 1 (March 2016): 40.

4. For a discussion of public political narratives under Putin, see Edwin Bacon, "Public Political Narratives: Developing a Neglected Source through the Exploratory Case of Russia in the Putin-Medvedev Era,” Political Studies 60, no. 4 (2012): 768-86. Lisa Wedeen identifies the uncovering of vulnerabilities in such political narratives as a hallmark of societal critiques; Ambiguities of Domination: Politics, Rhetoric, and Symbols in Contemporary Syria (Chicago, 2015). There is an ongoing debate in film studies about whether Zvyagintsev intended the film to be a critique, see the section, "A Tragic and Resonant Artistic Response," below.

5. According to Kinopoisk.ru as of February 2016.

6. In Russian: “бесконечно длинную ленту абсурдных, безумных, циничных и необъяснимых фактов, цитат, цифр и картинок, из которых состоит новостная повестка сегодняшней России. Каждую из них можно отдельно пошерить и показать друзьям в фейсбуке или родителям в “одноклассниках” ... они гарантированно переосмыслят свое отношение к бардаку, абсурду и цинизму, из которых состоит сегодня общественно-политическая жизнь нашей страны,” at https://navalny.com/p/5089/ (last accessed September 25, 2018). 
ideational politics because of their manifest engagement with the parameters of the post-Soviet social contract. These debates can be categorized as follows: (1) the authority debate prompted citizens to interrogate the quality of life under the current social contract and ask when and under what circumstances protest and resistance is possible and justified; (2) the agency debate gave rise to the question of heroes and whether those who lead or those who struggle against authority structures should be described as such; and (3) the authenticity debate entailed discussions about authentic Russian realities and values. A wide variety of voices contributed to these debates-Russian public intellectuals, clerics, journalists, and citizens-often fiercely disagreeing with each other. Such debates emerged after Leviathan's release, but they tie into themes with much deeper roots in Russian intellectual history. These deliberations merit attention, we argue, because they constitute Russia's contemporary ideological terrain precisely at a moment when most observers are focused on the widening reach of the Russian state's "propaganda," both domestically and abroad. An account of how societal or civic voices responded to the state's narratives, forging these debates about authority, agency and authenticity, reveals a very different and novel "map" of Russia's contemporary ideological terrain. ${ }^{7}$

This paper also offers an explanation as to how Zvyagintsev's Leviathan was able to prompt societal debates on such highly political issues. This question arises in the context of the Russian state's capacity, increasingly, to constrain circuits of societal debate (in particular, TV channels and widely read newspapers) and to shield itself from many artistic critiques that have not resonated widely beyond urban centers. ${ }^{8}$ There remain many societal and artistic challenges that explicitly and provocatively question Russia's state-sponsored political narratives, and the very existence of these critiques suggests that state-sponsored narratives have not saturated the post-Soviet ideological space as much as is regularly assumed under definitions of ideology that privilege state-sponsored doctrine. ${ }^{9}$ Still, these critical voices do struggle to be heard and understood. Pussy Riot's performances, for instance, for all their notoriety and brilliance, have remained inaccessible to most Russians. ${ }^{10}$ Zvyagintsev's Leviathan managed to trigger societal debates, we

7. We think of terrain and map here not in a geographical and physical sense, but in the sense of a necessarily simplified representation of a multi-dimensional and complex system.

8. We think of resonance largely as an empirical question: was an artistic or social critique understood and did it manage to trigger reactions by ordinary citizens, either affirming or rejecting this critique?

9. This assumption is particularly prevalent in IR scholarship that thinks of ideology as propaganda, e.g. Christopher Paul and Miriam Matthews, "The Russian 'Firehose of Falsehood' Propaganda Model: Why it Might Work and Options to Counter It," RAND Perspective series, Rand Corporation Expert Insights PE 198 (Santa Monica, 2016), at www. rand.org/pubs/perspectives/PE198.html (last accessed September 25, 2018); or Marcel Van Herpen, Putin's Propaganda Machine: Soft Power and Russian Foreign Policy (Lanham, MA, 2015).

10. For discussions of Pussy Riot's reception in Russia, see: Marina Yusupova, "Pussy Riot: A Feminist Band Lost in History and Translation,” Nationalities Papers 42, no. 4 (2014): 604-10; Regina Smyth and Irina Soboleva, "Looking beyond the Economy: Pussy 
argue, because of the way in which the film presented its critique of Russia's contemporary reality. It was the film's narrative structure that was the most effective challenge to the state's story: Zvyagintsev chose to tell a tragic tale that disrupts the romantic narrative underpinning Putin's historical and political claims. ${ }^{11}$ Without espousing a set of liberal values to oppose the state's nationalist, conservative agenda, the film's powerful narrative of the tragic fate of an ordinary Russian suggested to audiences that unlawful, unjust, and violent realities conspicuously continue into the present, rather than being a thing of the past. This artistic strategy-to present a tragic and inconclusive narrative that circumvents the pitfalls of explicitly espousing an alternative "utopia" of western democracy-was key in giving rise to wide-ranging societal debates about issues at the core of the Russian social contract.

This account of Russia's post-Soviet ideological terrain as dialogically constituted helps us gain a fuller notion of the ideational trends that shape politics in contemporary Russia. Attention to societal voices that challenge state-sponsored narratives also helps build a bridge between the literature on ideology and studies on civil society. Civil society in Russia has almost universally been deemed weak-a finding largely derived from a theoretical framework that measures the strength of civil society via associational capacity. However, more recent studies on post-socialist civil society have turned away from defining civil society as an organizational variable and examine ideational and discursive aspects of civic life. ${ }^{12}$ These studies have drawn attention to the potentially counterproductive effect of "western," or imported values on the development of indigenous social movements. Several authors have argued that the lack of resonance of "outside-in" ideas contributed to the weakness of civil society in post-socialist societies. ${ }^{13}$ Our efforts to chart ideology as a multi-dimensional state-society dialogue contributes to this research by highlighting a societal voice that did resonate and, by provoking wider social engagement with state-sponsored narratives, (re-)constituted Russia's ideological terrain. Rather than assume that societal groups critical of the state are motivated by liberal individualism, or that critiques of authoritarian trends are calls for democracy, this paper provides a nuanced account of the issues and values that are being debated in post-Soviet Russia and explains how one artistic voice was able to generate these debates.

Riot and the Kremlin's Voting Coalition,” Post-Soviet Affairs 30, no. 4 (2014): 258; Anya Bernstein; "An Inadvertent Sacrifice: Body Politics and Sovereign Power in the Pussy Riot Affair," Critical Inquiry, 40, no. 1, (2013): 220-41.

11. A number of film scholars and film critics refer to Leviathan as a tragedy: Anton Dolin,“Tri kita. Leviafan, rezhisser Andrei Zviagintsev,” Iskusstvo i Kino, no. 7 (July 2014); Vasilii Koretskii, “Gosudarynia rybka: O chem rasskazhet i kogo sboret 'Leviafan' Zviagintseva?,” Colta.ru, January 15, 2015, at www.colta.ru/articles/cinema/5963 (last accessed September 25, 2018). Tragedy was also identified as a feature of Zviagintsev's earlier films, see Nancy Condee, "Knowledge (Imperfective): Andrei Zviaginstev and Contemporary Cinema," in Birgit Beumers, ed., A Companion to Russian Cinema (Malden, Mass. 2016), 569, and Naum Kleinman, in Nancy Condee, 572.

12. See discussion of literature on civil society in section 2 .

13. Michael Waller, "The Environmental Issue in the East of Europe: Top-Down, Bottom-up and Outside-In,” Environmental Politics 19, no. 5 (September 2010): 831-49. 


\title{
Ideology-History-Civil Society; Contributions to Existing Debates
}

\author{
Ideology in Contemporary Russia
}

Many excellent studies on ideology in contemporary Russia have provided dynamic accounts of the ways in which elites have influenced the political landscape. Marlene Laruelle and Marina Peunova, most notably, have closely examined different Russian nationalist and Eurasianist narratives and what they imply for the relationship between Russia and other Soviet successor states. Elena Chebankova has outlined the political ideology of "Russian conservatism," while Peter Rutland has focused on ideational trends in economic thought. ${ }^{14}$ While these studies are extremely revealing, they largely focus on ideology as an elite-led, dominant discourse, and they often rely on analyses of speeches by Putin and well-connected Russian elites and intellectuals. Meanwhile, other studies have stressed that the state under Putin is responding to a relatively stable, public, and particularly Russian political ideal. Alexander Lukin has emphasized certain societal demands (the demand for a strong state, for example) as the drivers of elite ideology. ${ }^{15}$ Peter Kolesnikov similarly argues that Russian ideology is determined by the supply of elite rhetorical forms to relatively stable sets of societal demands. ${ }^{16}$ These are interesting accounts, too, but they treat societal demands as largely autonomously determined, obscuring the ongoing and mutually-constitutive conversation between elites and other social actors. ${ }^{17}$ Our research seeks to complement these existing accounts of post-Soviet ideology with a notion of ideology that is neither top-down nor bottom-up, but as essentially dialogic and reflexive. In other words, ideology is not an object or ability belonging to one class, but a discursive process involving all.

This dialogic definition of ideology relies on the work of Terry Eagleton and James Scott, who both write against the grain of widely-accepted Gramscian

14. Marlene Laruelle examines different Russian nationalist and Eurasianist narratives: In the Name of the Nation: Nationalism and Politics in Contemporary Russia (New York, 2009); Russian Eurasianism: An Ideology of Empire (Washington DC, 2009); and "The Three Colors of Novorossiya, or the Russian Nationalist Mythmaking of the Ukrainian Crisis," Post-Soviet Affairs 32, no.1 (2016): 55-77. See also Marina Peunova, “An Eastern incarnation of the European New Right: Aleksander Panarin and New Eurasianist Discourse in Contemporary Russia," Journal of Contemporary European Studies 16, no. 3 (2008); Elena Chebankova, “Contemporary Russian Conservatism,” Post-Soviet Affairs 32, no. 1 (2016): 28-54. See Peter Rutland's work on economic narratives, most recently, "The Place of Economics in Russian National Debates," in Pal Kolsto and Helge Blakkisrud, eds., Russian Nationalism Before and After Crimea: Nationalism and Identity, 2010-2017 (Edinburgh, 2018). Peter Pomerantzev sees state-sponsored ideology primarily as disinformation; see his Nothing Is True and Everything Is Possible: The Surreal Heart of the New Russia (New York, 2014).

15. Alexander Lukin, "Russia's New Authoritarianism and the Post-soviet Political Ideal,” Post-Soviet Affairs 25, no. 1 (2009): 66-92.

16. Peter Kolesnikov, Russian Ideology after Crimea (Moscow, 2015).

17. Part of why we embrace this notion of ideology is that there is no clear boundary between "elite" and societal narratives, and elite narratives are not unified. Laruelle's (2015) study of three overlapping ideological strands of the concept of Novorossiya illustrates this nicely. 
readings of ideology as hegemonic discourse. ${ }^{18}$ Eagleton's conceptualization of ideology treats elite/dominant discourse as meaningful only to the extent that it is always "addressed to another and lives only in the other's response." 19 In other words, dominant discourse becomes political when it is in dialogue with societal voices outside of the elite, since, for Eagleton, ideology is not the possession of one class, but rather a continuous, discursive process in which many sides take part. James Scott's landmark work on domination and resistance views ideology in similar terms. ${ }^{20} \mathrm{He}$ emphasizes the "imaginative capacity of subordinate groups to reverse or negate" dominant narratives and world views. ${ }^{21}$ Eagleton and Scott both highlight processes of ideological struggle rather than hegemonic assimilation, positing that such struggles are "the medium in which men and women fight out their social and political battles at the level of signs, meanings and representation," in Eagleton's terms. ${ }^{22}$ It is precisely this dialogic, non-hegemonic element that makes ideology an inherent site of political contestation. Attention to ideational politics is particularly urgent in contemporary Russia, because it is often seen as an autocratic state largely immune to societal reactions from below. In the ideational realm, this is an inaccurate impression (a claim detailed in the section on Russian Civil Society below), but one that is implicitly and inadvertently affirmed if ideology is seen as emanating hegemonically and uni-directionally from ruling elites or the state. Within a dialogic definition of ideology, the state does not hegemonically assimilate society into accepting its narratives, nor does the state follow a stable public political ideal. State and society narratives never fully merge, instead leaving traces on one another in ongoing dialogue and contestations.

To discern ideational contestation, we turn to cultural production as a compelling site for the investigation of dialogic ideology in post-Soviet Russia. Although cultural production has historically been marginalized in political science, a resilient strand of research has paid attention to literary texts, films, and art as taking part in politics. ${ }^{23}$ Political theorists, such as Slavoj Žižek and

18. Terry Eagleton, Ideology: An Introduction (London, 2007), 112-23. Eagleton discusses the nuances that differentiate the writings of Antonio Gramsci himself from subsequent strains of Gramscian interpretations of ideology. Specifically, Eagleton stresses that, while subsequent Gramscian studies of ideology have discussed ideology as dominant hegemony and false consciousness of the masses, Gramsci himself was attuned to the difference between hegemony and ideology, on the one hand, and the relational nature of ideology, on the other (122). Eagleton writes: "Gramsci normally uses the word hegemony to mean the ways in which a governing power wins consent to its rule from those it subjugates ... hegemony is also a broader category than ideology: it includes ideology, but is not reducible to it ... Ideology refers specifically to the way power-struggles are fought out at the level of signification; and though signification is involved in all hegemonic processes, it is not in all cases the dominant level by which rule is sustained" (113). Original emphasis.

19. Ibid., 46. Emphasis added.

20. James C. Scott, Domination and the Arts of Resistance: Hidden Transcripts (New Haven, 1990).

21. Ibid., 20; 90-92.

22. Eagleton, Ideology, 11.

23. Nick Dorzweiler, "Popular Culture in (and out of) American Political Science: A Concise Critical History, 1858-1950," History of the Human Sciences 30, no. 1 (2017): 138-59. 
Seyla Benhabib, have been influential in establishing a "politics of culture" in all its aesthetic, narrative, and agonistic contours, and many empirical studies have shown that cultural production-and films, in particular-are important sites for the experience, interpretation, and contestation of political narratives and ideologies. ${ }^{24}$ In the Soviet era, of course, art and culture were a battleground on which ideology was fought and shaped. ${ }^{25}$ In contemporary Russia, too, many artistic interventions aim to reveal pathologies of post-Soviet authority structures. ${ }^{26}$ The work of critical artists is important, because they participate in public discussions and frequently become a catalyst for public political debates. Maria Semendiaeva, for example, argues that Russia's contemporary artistic voices have demonstrated the capacity to challenge state dominance in the ideological arena by forcing the viewer to develop and express opinions. ${ }^{27}$ We follow the lead of these scholars in embracing cultural production as an appropriate site to detect ideological struggles, and turn to Zvyagintsev's Leviathan and surrounding societal debates as a particularly compelling and revealing case. ${ }^{28}$

First and foremost, we turn to this case because Leviathan generated a broad variety of societal reactions and debates on highly political questions. It was thus both critical and resonant. Critical resonance, that is, the fact

24. See Slavoj Žižek, The Sublime Object of Ideology (London, 1989), and Seyla Benhabib, The Claims of Culture: Equality and Diversity in the Global Era (Princeton, 2002). Notable examples of studies on art and politics are Cora Sol Goldstein, Capturing the German Eye: American Visual Propaganda in Occupied Germany (Chicago, 2009), and Anita Chari, A Political Economy of the Senses: Neoliberalism, Reification, Critique (New York, 2015).

25. Eagleton notes that Lenin himself saw culture as a "dense network of civil institutions," which the latter thought was severely lacking in tsarist Russia and, ironically, made revolution-cum-hegemonic overthrow possible (Ideology, 114). For an analysis of the artistic critique of socialist realism under the communist regime, see: Fitzpatrick, Everyday Stalinism: Ordinary Life in Extraordinary Times, Soviet Russia in the 1930s (New York, 1999); Richard Stites, Russian Popular Culture: Entertainment and Society since 1900 (Cambridge, Eng., 2000).

26. See Lena Jonson, Art and Protest in Putin's Russia (New York, 2015) and Birgit Beumers, Alexander Etkind, Olga Gurova, and Sanna Turoma, eds., Cultural Forms of Protest in Russia (New York, 2018).

27. Maria Semendiaeva made this point in her commentary on Pavlovskii's "Lubyanka's Burning Door" performance: "this image gives birth to the ideas and feelings in our minds and forces a lot of people to express their opinions about it." Semendiaeva, "Pavlenskii-Eto tochno iskusstvo? Voprosy pro aktsionizm, kotorye stydno zadavat'," Meduza (November 10, 2015), at www.meduza.io/feature/2015/11/10/pavlenskiy-etotochno-iskusstvo (last accessed September 27, 2018).

28. Strukov regards the state's participation in and subsequent manipulation of the debates surrounding Leviathan as reflective of a new, "post-propaganda" trend in the Putin-Medvedev regime's use of soft power. Interestingly, he points out the complex way in which state officials sought not to hegemonically "silence" critiques or assimilate these voices into "official discourse," but rather to bring critical voices into direct and antagonistic contact with official discourse for the purposes of achieving a kind of manicured global visibility-in short, to use narrative contestation as an opportunity to promote the state's "ideological position." This analysis of the state-society dynamics around the Leviathan debates supports our narrative, dialogic, and reflexive approach to ideology and similarly suggests a move beyond Gramscian notions of "propaganda" that were influential in twentieth-century conceptions of ideology; Strukov, "Russian 'Manipulative Smart Power,", 39-45. 
that a societal voice critical of Putin's regime was widely debated, is a remarkable accomplishment in contemporary Russia. In recent years-since 2014 in particular-the media landscape has been reshaped to effectively marginalize any criticism of the state by labeling such voices as unpatriotic or inspired by foreign powers trying to sabotage Russia. ${ }^{29}$ In this context, social critiques have often failed to resonate outside of small, urban, liberal, social strata, either because they simply do not reach broader audiences or because they were perceived as promoting values that are western, or alien to Russia. Against this background, the critical resonance achieved by Leviathan is no small feat.

Secondly, the film and its reception are political in that they explicitly engage with Russia's post-Soviet social contract. The film challenges the present-day implications of official narratives that position Putin as the guarantor of order and protector of citizens who rescued Russians from the divided state and chaos of the $1990 \mathrm{~s}^{30}$ It is important to emphasize that these official narratives are constructed versions of recent historical events. They are not simple chronicles, instead, they are highly intentional stories that connect particular events in the past and imbue them with meanings that serve political purposes in the present. Hayden White's work is helpful to understand the stakes here, as he describes history as just this kind of intentional, political story. For White, historical accounts have implicit narrative structures. Historical events are "emplotted" into stories that make use of one of four types of basic "emplotments"-romance, satire, tragedy, and comedy-each with different narrative structures that explain history. ${ }^{31} \mathrm{He}$ also argues that the choice of narrative structure in history writing is a highly political act: "everyone recognizes that the way one makes sense of [narrativizes] history is important in determining what politics one will credit as realistic, practicable, and socially responsible. ... Modern ideologies ... impute a meaning to history that renders its manifest confusion comprehensible...."32 White thus makes clear that representations of history are at the heart of political ideologies and contestation, and are inextricably involved in the political battles at the level both Eagleton and Scott describe-the level of signs, meanings, and representations. This is particularly useful for accounts of the ideological terrain in Russia, where representations of history are an overt and explicit element of political battles. ${ }^{33}$

29. Maria Lipman, "Russia's Nongovernmental Media under Assault," Demokratizatsiya: The Journal of Post-Soviet Democratization 22, no. 2 (2014): 179-90. See also Henry Hale, "The Myth of Mass Authoritarianism in Russia: Public Opinion Foundations of a Hybrid Regime,” Europe-Asia Studies 63, no. 8 (2011): 1357-75.

30. Chebankova, like many others, has argued that Putin's conservative project "is largely a reaction to ... the impoverishment, suffering and moral collapse of the 1990s, and the gradual economic recovery of the 2000s." Chebankova, "Contemporary Russian Conservatism," 29.

31. Hayden White, Metahistory: The Historical Imagination in Nineteenth-Century Europe (Baltimore, 1973).

32. Hayden White, The Content of the Form: Narrative Discourse and Historical Representation (Baltimore, 1987), 72-73.

33. Michael Bernhard and Jan Kubik pointed out for the post-Socialist context that "remembering the past is always a political process," in Bernhard and Kubik, Twenty Years After Communism (New York, 2014), 3. 
The claim here is that Zvyagintsev's Leviathan participated in debates about the historical narratives that underpin the Russian social contract under Putin, even though the film is not itself a historical narrative. It is first and foremost a filmic text about the present; the film clearly signals that events take place in the 2000s by way of a portrait of President Putin hanging in the mayor's office. Yet, we find that the film's ability to disrupt interpretations of the present order is tied to how it challenges state-sponsored narratives about the recent past. Putin's version of the past is a reflection of the events in the 1990s, but it is also meant to position the present in a particular way, and Leviathan casts doubt on this representation of the current moment. The brilliance of the film is that it thereby questions the origin myth, or the social pact between the state and its citizens under Putin, suggesting to some that the authority-bestowing covenant is flawed.

\section{Russian Civil Society}

An account of the state-society dialogue generated by Zvyagintsev's Leviathan also allows us to bridge the literature on ideology with studies on civil society, providing a novel angle for both. On a basic level, the existence of vibrant, critical and resonant societal voices shed doubt on the still very pervasive claim that civil society in Russia is exceptionally weak. More substantively, Zvyagintsev's Leviathan suggests that artistic voices play an important role in civic politics by generating sites for debates about foundational political assumptions and narratives.

The conclusion that post-Soviet civil society is weak has persisted, largely because many studies measure civil society by associational capacity and activity, relying on an organizational conception of civil society. ${ }^{34}$ These studies have many merits. They note that the state under Putin has increasingly intervened in the civil society sphere: ostracizing and squeezing out independent and foreign-funded civil society organizations, while rewarding and co-opting organizations it deems loyal and "useful." 35 The implications of these trends for Russian civil society are subject to ongoing debates. Sergei Ljubownikow and co-authors argue that Russia has acquired its own path-dependent form of civil society: "civil society po-russki." 36 Others have expressed serious concerns about the state-centric nature of Russian civic organizations, arguing that they cannot act as a check on the state's

34. Marc Howard, The Weakness of Civil Society in Post-Communist Europe (Cambridge, UK, 2003); and "Postcommunist Civil Society in Comparative Perspective," in Demokratizatsiya 10, no. 3 (2002): 285-305. See also Sarah Henderson, "Civil Society in Russia,” Problems of Post-Communism 58, no. 3 (May-June 2011): 11-27.

35. Henderson, "Civil Society in Russia." Henry Hale classifies Russia as a statist model of state-society relations, in "Civil Society from Above? Statist and Liberal Models of State-Building in Russia," Demokratizatsiya 10, no. 3 (2002): 306-21.

36. Sergej Ljubownikow, Jo Crotty, and Peter Rodgers, "The State and Civil Society in Post-Soviet Russia: The Development of a Russian-Style Civil Society," Progress in Development Studies 13, no. 2 (2013): 153-66. See also Julie Hemment's work: "Nashi, Youth Voluntarism, and Potemkin NGOs: Making Sense of Civil Society in Post-Soviet Russia,” Slavic Review 71, no. 2 (Summer 2012): 234-60. 
authoritarian tendencies. ${ }^{37}$ These assessments ultimately raise questions: given that loyalty and compliance with state requirements are key elements of the statist model, are societal forces capable of promoting change in the current system of government? If so, what are the motivations and pathways for various social actors to challenge the state?

Many studies of civil society under Putin largely assumed that societal groups that oppose the state's attempts to control this sphere will be motivated by liberal individualism and calls for more democracy. ${ }^{38}$ They were neither interested nor had the tools to map the shifting ideational battles over representations and meanings. ${ }^{39}$ More recently, however, ideational trends and normative models of Russian civil society are being scrutinized. Studies have pushed back against the idea that civil society is "apathetic." 40 Julie Hemment argues that foreign NGOs in Russia failed to be embraced by ordinary Russians because the ideas and issues they pushed forward seemed irrelevant to citizens against the background of other major problems faced by the population at the time. ${ }^{41}$ Similarly, Jessica Greenberg explains the phenomenon of social apathy not as an inherited legacy, but as a response to the "normative models of democratic success and failure" deployed by international policy makers. ${ }^{42}$ Lisa Sundstrom shows that only the groups promoting locally-resonant norms were successful in achieving social change, while NGOs that were perceived as promoting western norms failed. ${ }^{43}$ In the framework of these authors, one of the major causes of the weakness of civil society

37. In Henry Hale's terms: “although the statist model has led to some local successes, ... for the most part it has tended to facilitate arbitrary abuses of power by state authorities ...” Hale, "Civil Society from Above?” Laura Henry reaches a similar conclusion in "Complaint-Making Political Participation in Contemporary Russia," Communist and Post-Communist Studies 45, no. 1 (2012): 243-54.

38. For more on these debates, see Peter Rutland, "Putin's Path to Power," Post-Soviet Affairs 16, no. 4 (2000): 313-54; Lukin, "Russia's New Authoritarianism and the PostSoviet Political Ideal”; Moonyoung Lee, “Nostalgia as a Feature of 'Glocalization': Use of the Past in Post-Soviet Russia,” Post-Soviet Affairs 27, no. 2 (2011): 158-77.

39. That these battles are an important aspect of civil society is explicit in White, Eagleton, and Scott, and is also present in the work of scholars of civil society in democratic contexts; Craig Calhoun argues that "lively, diverse and innovative" engagement and public debate are an essential dimension of civil society, in "Civil Society and the Public Sphere," in Michael Edwards, ed., The Oxford Handbook of Civil Society (Oxford, 2011), 311-23.

40. The "legacy" school argued that civil society is organizationally weak, because of apathy and mistrust towards social organizations, i.e. because of ideational legacies inherited from the Soviet period. See Howard, "Postcommunist Civil Society in Comparative Perspective" and Henderson, "Civil Society in Russia."

41. Hemment is a critic of the legacy school, arguing that apathy is partially a dynamic response by post-Soviet citizens, rather than a static legacy, see Hemment, "Nashi."

42. Jessica Greenberg, “There’s Nothing Anyone Can Do About It': Participation, Apathy and 'Successful' Democratic Transition in Postsocialist Serbia," Slavic Review 69, no. 1 (Spring 2010): 41-64. She argues that western actors sponsor groups that fit with their own ideology of how post-socialist countries should transition and lack an understanding of their own normative compass.

43. Lisa McIntosh Sundstrom, "Foreign Assistance, International Norms, and NGO Development: Lessons from the Russian Campaign,” International Organization 59, no. 2 (2005): 419-49. 
in Russia and eastern Europe follows from the fact that NGOs promoted what Michael Waller calls "outside-in" values that lacked appeal for post-Soviet citizens. ${ }^{44}$ They highlight citizens' views that these values were irrelevant, at best, and harmful, at worst. ${ }^{45}$ In Paul Stubbs' words: "short-cuts to a democratic culture, and crude transplantations from elsewhere" often had "unintended negative consequences." 46 Our account of locally-resonant critiques and societal debates contributes to discussions on the failure of "outside-in" ideas by highlighting themes, questions, and rhetorical strategies that did resonate with a broad Russian audience (in contrast with studies that trace the failure of western liberalism). A close analysis of the authority, agency, and authenticity debates reveals efforts by societal actors to contest the states' narratives, and to ascertain viable alternatives to "outside-in" values. They merit attention, because they help us understand how artists, journalists, academics, and every-day citizens are embroiled in ongoing battles on an ideational plane, and, as such, are part of civil society activism.

\section{Three Nodes within Post-Soviet Russia's Dialogic Ideology: Putin's Narrative, Zvyaginstev's Leviathan and the Leviathan Debates}

If we accept the state-society dialogue surrounding Leviathan as constitutive of Russia's contemporary ideological terrain, how can we usefully grasp important features of this dialogue? Though ideology is constituted by a myriad of voices, for heuristic purposes, we trace the state-society dialogue as an exchange between three discursive nodes: Putin's narrative as represented in state media, the narrative critique in Zvyagintsev's Leviathan, and societal reactions to the film. These accounts are necessarily simplifications; they are proxies for less unified, more dynamic positions that constitute ideology in reality. ${ }^{47}$

\section{Romantic State-Sponsored Narratives of the Putin Era}

To trace official narratives of Putin's regime, we focus on a central theme taken up in the debates surrounding Zvyaginstev's Leviathan: Putin's role in forging the social contract that brings about order, security, prosperity, and the institution of a Hobbesian "Leviathan." The first post-Soviet decade is commonly remembered as tumultuous, chaotic, and largely ungoverned. In state-sponsored narratives, Putin's response to the chaos of the nineties

44. Waller, “The Environmental Issue.”

45. See for example, Stefanie Kappler and Oliver Richmond, "Peacebuilding and Culture in Bosnia and Herzegovina: Resistance or Emancipation?," Security Dialogue 42, 3 (2011): 261-78; Greenberg, “'There’s Nothing Anyone Can Do About It'” Michele RivkinFish, Women's Health in Post-Soviet Russia: The Politics of Intervention (Bloomington, 2005).

46. Paul Stubbs, “Civil Society or Ubleha,” in Helena Rill, Tamara Šmidling, and Ana Bitoljanu, eds., 20 Pieces of Encouragement for Awakening and Change: Peacebuilding in Former Yugoslavia (Belgrade, 2007), 215-28.

47. State-sponsored doctrines under Putin have in fact been remarkably flexible; see Rutland, "The Place of Economics." 
becomes crucially important. ${ }^{48}$ Against the backdrop of instability, disorder, and lawlessness (беспредел), Putin enters as the handpicked successor of Boris Yeltsin, tasked with addressing the disorder of the nineties. The centralization of power, implementation of the "power vertical" (вертикаль власти), taming of the oligarchs, re-privatization of energy assets, and violent "appeasement" of Chechnya were all informed by this goal. According to state-sponsored narratives, President Putin succeeded in establishing a strong state, achieving stability and prosperity, and re-affirming Russian values. ${ }^{49}$ Per the state's telling of events, these achievements were only possible because of the strong, paternalistic, and authoritative leadership that created order out of the chaos. ${ }^{50}$ State-sponsored narratives tirelessly promote Putin as the personal and heroic guarantor of this perceived stability and recovery. We want to neither detract from the suffering of the 1990s, nor dispute the relative stability under Putin; we are interested in how this period is characterized and what functions it serves in the state's narratives.

White's notion of emplotted history is helpful for understanding Putin's reliance on a particular version of the country's recent past. If we understand history as a necessarily and intentionally emplotted narrative, we see that the state-sponsored narratives of Putin's success and the implied interpretation of the shift from past to present are romantically emplotted. The romantic narrative structure is defined by a number of elements, according to White and others: a central characteristic is the triumph of good over evil, which serves as the condition for renewal and happiness. This triumph usually comes in the form of a hero who redeems himself through transcendence over the divided state in which men find themselves. We see both of these elements at play in Russia's state-sponsored narratives. Putin is clearly the sober, physically strong, and sharp hero who personally saved Russia from the horrors of the nineties. In his early years as president, Putin frequently stressed the need for the state to "remove people's fears" and foster "political stability and economic prosperity" in the period that followed the "stormy decade" and the "difficult period" of society being "deeply divided by complex social conflicts." 51 This narrative

48. This exceptional sense of disorder stemmed from multiple sources of rapid change: the decay or disappearance of Soviet-era institutions and norms, the unrestrained and destabilizing influence of market liberalization, and the (unexpected) difficulties in building new institutions to regulate social, political, and economic life.

49. Rutland cites Putin as referring to the state as "the source and guarantor of order" in the aftermath of the "excessive costs" associated with the "experience of the 90s." Rutland, "Putin's Path to Power," 343.

50. It is interesting to note that these same themes and emplotments run parallel to those emphasized in the history textbooks sanctioned by the state that take part in the rehabilitation of Josef Stalin-a historical rehabilitation in which the Putin regime has taken a guiding interest. See Todd Nelson, "History as Ideology: The Portrayal of Stalinism and the Great Patriotic War in Contemporary Russian High School Textbooks," Post-Soviet Affairs 31, no.1 (2015): 37-65.

51. Vladimir Putin, "Annual Address to the Federal Assembly of the Russian Federation" (April 3, 2001), at en.kremlin.ru/events/president/transcripts/21216 (last accessed September 27, 2018). And Vladimir Putin, "Annual Address to the Federal Assembly" (April 2, 2007), at en.kremlin.ru/events/president/transcripts/24203 (last accessed September 27, 2018). 
continued to be important throughout the 2000s and through to the moment Zvyagintsev's film was released..$^{52}$

The narrative works hard to show that the "divided state" and disorder (беспредел) of the 1990s have been overcome. On this point, many commentators in Russia and abroad have compared the centralization of power under Putin with Thomas Hobbes's account of the establishment of the sovereign out of "the state of nature." 53 The social contract under Putin in essence entails acquiescence with the centralization of authority in exchange for stability, order, and security. ${ }^{54}$ This mirrors the conditions under which the social contract is forged in Hobbes's Leviathan. In Hobbes, the state of nature is a brutal, violent, and primitive stage of human existence, as well as a war of all against all; Russia's experience in the 1990s is presented as equally violent and lawless. Hobbes's leviathan is an "artificial person" that is brought into existence "when a multitude forms itself into such a unity by instituting a representative." 55 This "artificial person" is the sovereign that is covenanted to be stronger than any one natural person who is part of the multitude thus unified. ${ }^{56}$ Hobbes argues that only in this manner can natural man achieve the primary political goal of guaranteeing each the right to security of person. In Russia's state-sponsored narrative, the establishment of a unified state under Putin's sovereign authority resembles an overcoming of the divided and violent state of recent history. Both Putin's narrative of the state and Hobbes's theory of sovereignty, then, involve heroic action

52. Over the first decade of the 2000s, terrorism took the place of the "threat" and disorder, but Putin continues to refer back to the threats of the 90s: "We know what the aggression of international terrorism is. Russia faced it back in the mid-1990s, when our country, our civilian population suffered from cruel attacks. We will never forget... . These tragedies took thousands of lives. ... We almost succeeded in expelling terrorists from Russia, but are still fighting the remaining terrorist underground. This evil is still out there." Vladimir Putin, "Presidential Address to the Federal Assembly" (December 3, 2015), at en.kremlin.ru/events/president/news/50864 (last accessed September 27, 2018).

53. We bring Hobbes into the discussion here for two reasons: first, because Zvyangintsev's Leviathan draws on Hobbes, and secondly, because Russia's state-sponsored narratives on the origins, nature, and role of the sovereign hews remarkably close to readings of Hobbes that stress the "heroic" quality of Hobbes's theory, see e.g. Sheldon Wolin, Hobbes and the Epic Tradition of Political Theory, Andrews Clark Memorial Library Seminar Papers (Los Angeles, 1970). See also Vladimir Shlapentokh, "Hobbes and Locke at Odds in Putin's Russia,” Europe-Asia Studies 55, no. 7 (2003); 981-1007, or Vadim Volkov, Violent Entrepreneurs: The Use of Force in the Making of Russian Capitalism (Ithaca, NY, 2002), and Oleg Kharkhordin, "Andrei Zviagintsev kak zerkalo russkoi evoliutsii," Vedomosti, February 11, 2015, at www.vedomosti.ru/newspaper/articles/2015/02/11/russkiimir-nastoyaschii-leviafan (last accessed September 27, 2018).

54. Nikolay Petrov, Maria Lipman and Henry Hale have described the order-andprosperity-for-acquiescence exchange as a "non-intrusion pact," with the state providing "steady economic growth, Russia's perceived return to global leadership, a sense of stability, nonintrusive government, and a feeling that the country is being guided by a strong and capable leader" in return for their abstinence from politics. See Petrov, Lipman, and Hale, "Three Dilemmas of Hybrid Regime Governance: Russia from Putin to Putin," PostSoviet Affairs, 30, no.1 (2014): 1-26.

55. Quentin Skinner, Hobbes and Civil Science, Visions of Politics 3:3 (Cambridge, UK, 2002), 198.

56. For natural man "can create 'that great Leviathan' which 'is of greater stature and strength' than natural man.” See Wolin, Hobbes, 23. 
(of the sovereign in both), transcendence of the world of experience (postSoviet transition in Russia; state of nature in Hobbes), and the promise of new conditions emergent out of seemingly changeless processes (security; order), fulfilling all three central elements of romance in White's account. ${ }^{57}$ Ultimately, both narratives of the state suggest that conflict and disorder can be reconciled and transcended.

\section{A Tragic and Resonant Artistic Response: Zvyagintsev's Leviathan}

In order for ideology to exist as we have defined it above, we need to be able to show evidence of relevant dialogic exchanges on foundational issues of Russian political and social life. There have in fact been significant critical responses to Putin's narrative, many of which have emerged from the sphere of cultural production. Peter Pavlensky's radical art draws attention to the increasingly authoritarian character of state policies. ${ }^{58}$ The public performances of Voina and Pussy Riot are satirical critiques of many aspects of the Putin/Medvedev political program: pro-nativist policies, police brutality, and the hand-over of power from Medvedev back to Putin. Pussy Riot's activism is a direct critique of values espoused by the Putin regime: they mourn the failure of democratic, liberal, and individualist values to take hold. ${ }^{59}$ The performance "Free the Cobblestones" (2011) called on audiences to "turn Red Square into Tahrir." 60 Yet, Pussy Riots and other artists' critical messages were frequently marginalized as un-Russian and inspired by foreign values. Pussy Riot's reliance on feminism to critique authority structures and on punk-rock as a provocative tool were part of the reason why it did not receive a broad acceptance in Russia and were fiercely rejected by many. Even Russian feminist groups were lukewarm about endorsing the group's message. ${ }^{61}$

Zvyagintsev's Leviathan not only received tremendous critical acclaim for its artistic value in Russia and abroad, the film was also immediately

57. White, Metahistory, 8-9.

58. Among Peter Pavlensky's most well-known performances are the "Seam" (the artist sewed his mouth shut in support of Pussy Riot) and "Lubyanka's Burning Door" (the artist set on fire the door of KGB headquarters in Moscow). Other societal voices include Dmitry Bykov's “Grazhdanin Poet” project, a number of oppositional blogs; e.g. Valerie Sperling's account of the feminist activist blog "Feministki" in Sex, Politics, and Putin: Political Legitimacy in Russia (New York, 2014), 247. Fabrizio Fenghi points out that the National Bolshevik Party has roots in an artistic critique, see his "Making Post-Soviet Counterpublics: The Aesthetics of Limonka and the National-Bolshevik Party, Nationalities Papers 45, no. 2 (2017): 182-205.”

59. For the band's critique of Putin regime and the hope they place in individualism, see band member's closing statements in N+1 Magazine, at https://nplusonemag.com/ online-only/online-only/pussy-riot-closing-statements/ (last accessed September 27, 2018).

60. Masha Gessen, Words Will Break Cement: The Passion of Pussy Riot (New York, 2014), 73. Pussy Riot’s “Punk Prayer” (2012) explicitly criticized Vladimir Putin’s exploitation of the aesthetics and symbolic power of the Orthodox Church.

61. Sperling, Sex, Power and Politics. See also Bernstein, "An Inadvertent Sacrifice" (2013) on the Russian response to Pussy Riot. 
recognized as a trenchant critique of the ways in which power and politics work under Putin. ${ }^{62}$ Zvyagintsev himself said his goal was to portray the relationship between an individual and power (пристально посмотреть на то, что происходит ... [на] человек[а] и власть ... .). ${ }^{63}$ Film scholars have debated whether the film should or should not be seen as a political critique: Julian Graffy is struck by the film's "social engagement" and "civic boldness," while Nancy Condee emphasizes Zvygatinsev "ambition to deliver a religious message, not a political one." ${ }^{44}$ On the one hand, Zvyagintsev has resisted readings that "reduce" the film to a political message, wanting to uphold its artistic value and a claim that it speaks to broader truths about human existence. On the other hand, he also confirmed that the parallels to Hobbes's Leviathan were absolutely intentional and the film is replete with references to politics. ${ }^{65}$ Images of Soviet and post-Soviet leaders make several appearances, for example: their portraits are used as shooting targets and Putin's portrait is seen hanging in the mayor's office, as if overlooking the latter's actions. What is most important for our purposes is the great number of commentators who understood the film as deeply political and critical of Putin's political system. Boris Nemtsov argued cogently shortly before he was killed: "Putin's era will be judged by this film" (по этому фильму будут судить об эпохе Путина), and that the film will serve as a monument to "Putinism." 66 Similarly, Dmitry Bykov saw the film as depicting the atmosphere in Putin's

62. Leviathan won several film prizes, in Russia as well as internationally, in 2014. While clearly perceived as critical, it was well-known (and indicated in the film's opening credits) that the film received substantial financial support from the Ministry of Culture. What this tells us is that "the state" is not a coherent actor: the Ministry's decision-makers must have initially assessed the film as a valuable artistic contribution, either not objecting to or not anticipating the film's provocation.

63. Zvyagintsev: “[Цель фильма была] ... рассказать о правде, пристально посмотреть на то, что происходит между нами, между социальными слоями, то есть-человек и власть, человек и родня.” See “Zviagintsev ne planiruet otkazyvat'sia ot "ekzistentsial'noi beznadegi" v svoikh novykh fil'makh," TASS (January 28, 2005), at https://tass.ru/kultura/1728833 (last accessed September 27, 2018).

64. Julian Graffy, “Andrei Zviagintsev: Leviathan,” Kinokultura 48 (2015), at www. kinokultura.com/2015/48-r-leviafan.shtml (last accessed September 27, 2018), and Nancy Condee, "Knowledge (Imperfective)" (2016). Vasillii Koretskii similarly rejects an overtly political reading of the film, arguing that this comes at the expense of Zvyagintsev's intentions to tell a broader story, see "Gosudarynia rybka."

65. In an interview with Ksenia Sobchack, Zvyagintsev insisted on the plot's universal applicability; at the same time, he admitted that Russian realities were indeed reflected in the film, see "Andrei Zviagintsev-Ksenii Sobchak o pobede "Leviafana", Sobchak Zhivyem/TV Rain, YouTube video, 58:17, posted by TV Rain, March 6, 2015, at https://www. youtube.com/watch?v=WRtBoFzzEfU (last accessed November 16, 2018).

66. Nemtsov says: “Я думаю, что по этому фильму будут судить об эпохе Путина. И когда его не станет, этот фильм обнажится и станет памятником 'путинизму.' Фильм сильный, а сила его в том, что это честный фильм. Он резко контрастирует с ложью и пропагандой, которая свирепствует на телевидении.” He continues to say that the strength of Leviathan derives from the "honesty" of the movie, pertinent to our discussion in the section on Leviathan debates, below. Boris Nemtsov, "Leviafan mozhno bylo sniat' iv Moseitsevo" Yarnovosti, February 6, 2015, at https:/yarnovosti.com/news/ Leviafan_v_Moseisevo/ (last accesses 27 September 2018). 
Russia. ${ }^{67}$ Ksenia Sobchak noted that "it is a movie about the inner-workings of Russia." ${ }^{88}$ Other commentators have even argued that the film's depiction of authority has the potential to unsettle a fragile quiescence with Putin's regime. Vyacheslav Kostikov, a journalist and former press secretary for Boris Yeltsin, argued that the negative responses to the film by elites close to Putin (what he calls the "new Nomeklatura") stems from the fact that the Russian government is afraid (побаивается) of the truth. ${ }^{69}$ Opposition politicians were not the only ones who saw the film as critical of authorities; societal voices loyal to the state noted this as well. Vsevolod Chaplin, a high-ranking Orthodox cleric argued that the film was made to please the west and that it asserts an "anti-state" cult (культ антигосударственности). ${ }^{70}$ Diakon Andrey Kuraev observed that "our Leviathan" (the Russian state) might not like the film. ${ }^{71}$ Two United Russia Duma deputies also explicitly referred to Leviathan's critical nature, noting that the film "discredits authorities, interests, and values of the Russian Federation," and called for a ban on films of this kind. ${ }^{72}$

Before detailing the content of social reactions, we need to understand why Leviathan resonated widely and how it was able to generate such vivid reactions. We argue that Leviathan's narrative structure is key to understanding both. The film unfolds as a tragedy: it generated debates and disrupted dominant, romantic narratives not by proposing an alternative set of values or an alternative utopia, but by telling a bleak story of human failure and struggle with the state. In this way, the film positions itself in stark contrast to Putin's romantic narrative. In Leviathan, authorities are featured as the source of suffering, ruining rather than protecting and improving ordinary people's lives. The film also posits that the violent, unjust past continues and has not been ushered out by a more peaceful, orderly present established by Putin. This is first and foremost evident in Leviathan's many representations of violence. The scene in which the mayor's thugs beat up Dima and urge him at gunpoint to stop meddling resembles the "chaotic" nineties rather than Putin's stable, rule-governed 2000s. The continuation of the unjust past is also evident in the property dispute at the heart of the film's plot. Russia's first post-Soviet decade was replete with property disputes of the kind characterized in the film. In Zvyagintsevs' Leviathan, however, violence and expropriation, as

67. Dmitri Bykov, “Learn, We Are Fun!,” Novaya Gazeta, no. 2, January 14, 2015: ““Левиафан’ мрачное и сильное кино, по которому когда-нибудь будут судить об атмосфере путинской России.”

68. Comment was published in "Ksenia Sobchak: "Leviafan"- eto kino o tom, kak ustroena Rossiia," Argumenti $i$ fakti, January 13, 2015, at www.spb.aif.ru/culture/ person/1422816 (last accessed September 27, 2018).

69. Comment was published in "Viacheslav Kostikov: liudi khotiat byt'v soglasii s sovest'iu," Argumenty i Fakti, March 24, 2015, at www.aif.by/social/nazlobydnya/ item/36143-kostikov.html (last accessed September 27, 2018).

70. At www.interfax-religion.ru/?act=news\&div=57959 (last accessed September 27, 2018). 2018).

71. At https://diak-kuraev.livejournal.com/718249.html (last accessed September 27,

72. Duma deputies from Tyumen, at www.newsprom.ru/news/Obschestvo/208327. html (last accessed September 27, 2018). 
well as the pervasive threat of both, are a mark of the present, rather than the transcended past. The film thus challenges the state's interpretation of recent history as reconciliation and liberation with a narrative of somber resignation and literal incarceration-but, importantly, without embracing democracy, individualism, and other "outside-in" values. ${ }^{73}$

The implications of the film's tragic narrative structure for Russia's current political reality were not lost on Russian audiences that viewed and commented on the film. Although Kolya, the hero, falls and fails to achieve the task he attempts, these narrative events are not wholly threatening to moviegoers who witness them. Audiences of tragedies gain something invaluable in return for their witness: according to White, they gain an "epiphany" of the human condition. ${ }^{74}$ Tragedy prompts audiences to grapple with the consequences of presented dilemmas and to gain insight as they watch characters struggle and confront these dilemmas. The characters in Leviathan (along with the audiences of the film) are indeed forced to consider a series of questions: whether resistance to the sovereign "leviathan" is justified; whether faith in "the facts" (what is just and lawful) is enough to secure legal victory in their town; whether keeping a family together is worth giving in to authorities. Typical of a tragedy, however, these questions remain unreconciled in the film. ${ }^{75}$ There are no clear answers. Yet, the film's unresolved questions catalyzed social debate, and it is this catalytic capacity of tragedy that runs directly counter to Putin's romantic myth: one of the central aims of the romantic and conservative narrative is to ease "the condition of epistemological uncertainty." 76 The effect of a romantic narrative is to provide reconciliation, reassurance, and answers, in contrast to the effect of tragedy, which unsettles audiences and forces reflection. This tension between certainty and uncertainty, the reconciled and unreconciled, corroborates both Eagleton's and White's linking of ideology with civil society. Leviathan's tragic sensibilities provoked precisely these kinds of ideological debates, as audiences were prompted to engage with the state's assurances and its version of history, and assess the ability of dominant narratives to reconcile the many contradictions - the "mess, absurdity and cynicism," in Naval'nyi's words-created by everyday realities and encounters with the state.

\section{Civic Response: The Leviathan Debates}

The tragedy that Leviathan offered to Russian audiences provoked exceptionally critical engagement with the state-sponsored narratives in traditional

73. See Jonson, Art and Protest in Putin's Russia, 51. Jonson highlights art that seeks an alternative understanding of the country's past, future, and present against Putin's discourse on state nationalism.

74. White, Metahistory, 9: "In Tragedy ... the fall of the protagonist and the shaking of the world he inhabits which occur at the end of the Tragic play are not regarded as totally threatening to those who survive the agonic test. There has been a gain in consciousness for the spectators of the contest. And this gain is thought to consist in the epiphany of the law governing human existence which the protagonist's exertions again the world have brought to pass."

75. Nancy Condee, argues similarly, that audiences do not gain knowledge, whether “suffering . . . finds redemption,” Condee, “Knowledge (Imperfective)” (2016): 572.

76. Chebankova, "Contemporary Russian Consevatism,” 36. 
media and online forums. Such engagement is at the heart of dialogic ideology, and reveals foundational debates that constitute Russia's post-Soviet ideological terrain. This engagement is also an example of domestic, locally resonant societal debates that do not flow directly from a promotion/rejection of western values. The analysis below highlights three inter-related themes that incited debate, showing for each that the film did not propose one path or one set of values as superior, but prompted reflection through elements of a tragedy and by drawing on well-known Russian literary traditions.

\section{Debate 1: Authority-Implications of "Raw Life" and Suffering at the Hands of the Sovereign}

The nature of authority is unambiguously depicted in Zvyagintsev's Leviathan. Representatives of the state (the head of the police, prosecutor, judge, and mayor) wield absolute power over citizens, or subjects. Kolya, his friends, and his family are harshly treated, judged unfairly, dispossessed, brutally injured, and imprisoned by representatives of the state. The ways in which power functions are also painted in clear lines: authorities are hierarchical, violent, corrupt, unjust, and opaque. Authorities behave as if they are entitled to power, treating others as inferior and demanding complete submission. This is evident, for example, when the mayor visits Kolya's house and hurls insults at him: he tells him that he has no rights (у тебя никаких прав, не было и никогда не будет), that he is a mere "insect" (насекомое), and that "everything here is mine" (все здесь мое).$^{77}$ At the same time, the state fails to carry out duties it promised to fulfill: Kolya's teenage son is abandoned for days despite assurances that authorities would take care of him, for example.

The protagonists initially harbor hopes that a rational, legal appeal and the support of friends in town could sway, even destabilize power, but these hopes are unequivocally shattered. Not only do Kolya's friends (Anna and Alexei) fail to attend court hearings, at the end of the film they question Kolya's innocence and end up taking the state's side. The court scenes reveal that the state is immune to Dima's legal appeal. Later scenes further demonstrate that Dima's talent and legal knowledge are useless in fight against the "leviathan": the responsible state official disappears, as Dima tries to submit a simple complaint to the police. As it happens, the state's authority figures are only accountable to the clergy and the Orthodox Church, but even this turns out to be a cynical bargain. The mayor and his cronies receive the clergy's endorsement; in return, the mayor delivers material contributions to the church, obtained through the powers of eminent domain. This bargain is described as a "good, even moral deed" (благое дело) by the powerful parties involved. Yet, at the end, the audience finds out that Kolya's house, life, and love were destroyed to make room for the construction of a new churchhence suggesting that the morality of the powerful is unjust. ${ }^{78}$ There are many

77. Oleg Zintsov highlights this in his review of the film: "V chem vinovat geroi 'Leviafana,", Vedomosti, February 4, 2015, at www.vedomosti.ru/lifestyle/articles/2015/02/04/ chelovek-kotoryj-ne-ponyal (last accessed September 27, 2018).

78. Note that the use of eminent domain to construct churches has been controversial in a number of instances in recent history, most notably the Torfianka Park conflict in Moscow. 
moments of laughter and intimacy with friends and family in the film, but friendship, family, and love are ultimately destroyed as authorities get their way. Whether Nikolai submits (as one humble cleric suggests) or continues to rebel, he ends up in misery. Leviathan relentlessly exposes audiences to the suffering of an ordinary Russian at the hands of a leviathan that is more monster than savior. Russian film scholar Anton Dolin singled out this relationship between authority and the citizen as the film's central message: "the whole movie shows that the state treats man poorly, corners him. It deprives him not only of space, but of allies, until he is left alone-instead of residing on his land, he is confined in a prison cell." 79

The film's "civic boldness," in Graffy's terms, raised a provocative question among Russian viewers: if the state violates its side of the social contract by injuring and unjustly imprisoning citizens, does it thereby give citizens grounds for rebellion? Oleg Kharkhordin notes that the film was critical because it showed how protagonists' lives were "nasty, brutish and short," despite the social contract with the leviathan. ${ }^{80}$ As noted previously, the film is very explicit about the source of human misery-unconstrained authorities, a coopted judiciary, and corrupt clerics. This revelation about the injuries that the state inflicts on citizens is damaging to Putin's romantic narrative of post1990s Russia, suggesting that the state is the enemy that violently interferes with the private lives of its citizens. ${ }^{81}$ The dissonance between human suffering and Putin's narrative is also explicit in the reaction of a Russian observer who is, notably, not a member of the urban intelligentsia-Tatyana Starinko, an employee of the fish factory in Teriberka, where the movie was filmed. She observed: "The scandal [about the movie] was because the film showed raw life, exposed. But that's how it is! And sometimes, it's all you need to get things moving," adding, "If they made more movies like this, maybe people would start thinking."

Dolin's, Kharkhordin's, Starinko's and others' reactions suggest that Leviathan managed to bring together at least four perspectives on the question of whether the covenant with the state still holds: Kolya's, Putin's, Hobbes's, and the bible's. Kolya's tragic story and the suffering of his family suggest a

79. Dolin, “Tri kita”: “Весь фильм показывает, как государство оттесняет человека, загоняет его в угол. Лишает не только пространства, но и союзников, пока он не останется в одиночестве и вся его земля будет ограничена тюремной камерой."

80. Kharkhordin, “Andrei Zviagintsev,” Vedomosti.

81. In public opinion surveys, Russians have identified government noninterference and lack of crime as markers of a "normal society." Against this background, Leviathan then paints a picture of Russian society that is at odds with both the expectations of Russian citizens and the narratives of the state itself. See Lukin, "Russia's New Authoritarianism and the Post-Soviet Political Ideal," 77.

82. Interviewed by Anna Arutunyan, in "In Russia, Oscar-nominated 'Leviathan' Opens Old Wounds," USA Today, February 12, 2015, at www.usatoday.com/story/news/ world/2015/02/12/russia-oscar-leviathan-film/22995465/ (last accessed September 27, 2018). This concern echoes Chebankova's recent observation that one of the "substantive questions pondered by Russian society today" is the "role of the state and societal expectations placed upon it." She also notes that another pressing question is the "treatment of historic myths and their application to the present." Chebankova, "Contemporary Russian Conservatism," 30. 
"not so sure" answer to questions concerning citizens' rights to break the covenant with the state. This answer is different from the one provided by Hobbes, who stipulates that once a transfer of rights has taken place, it is the duty of the subject "not to interfere with the execution of their commission, since the right to act as they think best in discharging their task is precisely what has been voluntarily handed over. ..."83 The Russian state's answer follows Hobbes: citizens do not have the right to challenge the social contract, no matter what; this position has been especially clear in the recent crack-down and imprisonment of protesters. This is also the answer that is given by the biblical story of Job, which is woven throughout the film: it suggests that resistance to God's authority is hubris, but that faith will ultimately defeat the monstrous Leviathan. ${ }^{84}$ The film's achievement is not to endorse any one answer, but to allow audiences to deliberate the question on their own. Finally, Kolya's total impotence to challenge the mayor adds another layer to the question about the right to resistance, namely that of capacity and agency, discussed next.

\section{Debate 2: Agency-Can the "Little Man" Be the Hero?}

While Leviathan does not endorse a particular path for action to oppose unjust authorities, it does leave viewers with a clear image of the life of an everyday hero. The film assumes the perspective of Kolya and his family-ordinary Russians-exposing the painful details of their struggles. Through this focus, Leviathan engages with the state-sponsored narrative that identifies Putin as the ultimate hero and stirs a debate on who should be at the center of history and ideology, or who has agency in history.

Many commentators on the film have sought to compare the fate of Kolya with that of "little men" in their own communities. Boris Nemtsov and Alexei Naval'nyi both explicitly encouraged such comparisons. Several journalists have used the film to make sense of local events: a journalist from Rostov drew parallels between a local family's situation and Kolya's fate, calling it an instance of the endless conflict between "the little person" and the arbitrary authorities. ${ }^{85}$ Similarly, a TV journalist from Moscow argued that Leviathan's plot reflects the experiences of many "actual people," who have turned to her for help with similar grievances. ${ }^{86}$ The film provoked these reactions by following a well-established Russian narrative tradition that draws attention to the "little man" as an everyday hero. ${ }^{87}$ Artists and writers in imperial

83. This question is widely debated by the political theory literature on Hobbes, see Skinner, Hobbes and Civil Science.

84. In this biblical story, God tests Job's obedience and faith by inflicting suffering in the form of a monster, the Leviathan. God calls on Job to be faithful, as only those who obey unconditionally can defeat the Leviathan. A fuller discussion of the Zvygintsev biblical references is important, but outside the scope of this paper.

85. Viktor Tarasenko, see at versia.ru/semya-vidnogo-rostovskogo-politika-poluchilazemlyu-krestyanin-lyog-v-mogilu (no longer available).

86. Marianna Maksimovskaya, quoted in Dmytro Desiateryk, "A Long Unfortunate Life: Leviathan Tells How the State Crushes a Small Man Without Obstruction,” Den', no. 2, January 20, 2015, at https://day.kyiv.ua/en/article/culture/long-unfortunate-life (last accessed September 27, 2018).

87. For a recent overview of this tradition, see Sheetal Anand, "Changing the Psyche of the ‘Little Man’: From Pushkin to Dostoyevsky,” Russian Philology 19 (2000): 53-59. 
Russia participated in critiques of historically-dominant narratives by showing images and telling stories about peasants, serfs, and other marginalized people caught in the imperial machine of top-down modernization. Leviathan echoes Aleksandr Pushkin's “Bronze Horseman," a foundational and familiar text to broad Russian audiences. Both narratives involve marginalized actors from the lower rungs of society as main characters, whose lives are destroyed as collateral damage in the struggle between larger forces. ${ }^{88}$ Later, socialist realism elevated everyday citizens and workers as the heroes of history, but their experience needed to be carefully tailored in a particular mold, in order to serve the goals of the state and embody the "lofty ideals, dreams, and heroism of Soviet man." ${ }^{89}$ Everyday realities experienced by socialist heroes were explicitly meant to provide moral guidance and tended to focus on particular types of heroes-workers, soldiers, and others who embodied the utopias of Soviet socialism..$^{90}$ At the same time, Soviet artists and authors frequently challenged socialist realism's insistence on particular heroes and their moral universe. $^{91}$

One of the most successful and popular filmic genres to shift its focus away from these socialist heroes to regular, everyday protagonists in Soviet Russia was chernukha. Chernukha as an artistic genre showed "the seamy underside of Soviet life and ideology" through dystopian, graphic, and pessimistic narratives of individuals, and powerfully-conveyed hopelessness, cynicism, collapse, and decay. ${ }^{92}$ Films in this tradition seek to intentionally shock audiences, most often with explicit depictions of filthy, bodily, scatological, and other aspects of everyday experiences.$^{93}$ Much like chernukha films,

88. John Kevin Newman, “Pushkin’s 'Bronze Horseman' and the Epic Tradition,” Comparative Literature Studies 9, no. 2 (1972): 180; Maria Banerjee, "Pushkin's 'The Bronze Horseman': An Agonistic Vision,” Modern Language Studies 8, no. 2 (1978): 47.

89. Victor Terras, ed., Handbook of Russian Literature (New Haven, 1985), 430.

90. Stites, Russian Popular Culture, 67.

91. Svetlana Alexievich's work depicts an alternative reality of war, substituting “the narrative of victory for the narrative of trauma" as experienced by everyday actors, rather than military heroes. Alexievich gives voice to those who were often voiceless in the dominant narrative of war: instead of male soldiers on the battlefront, she reveals the realities of the lives of women during the war, see Alexievich, War's Unwomanly Face, (Moscow, 1988).

92. Eliot Borenstein, Overkill: Sex and Violence in Contemporary Russian Popular Culture (Ithaca, 2008), 13. The discussion of the chernukha here draws mostly on Borenstein and on Seth Graham, "Chernukha and Russian Film," Studies in Slavic Cultures, no. 1 (January 2000): 9-27. See also Moonyoung Lee, “Nostalgia as a Feature of 'Glocalization': Use of the Past in Post-Soviet Russia," Post-Soviet Affairs 27, no. 2 (2011): 158-77, and Elizabeth Skomp, "Review: Overkill: Sex and Violence in Contemporary Russian Popular Culture by Borenstein, Eliot," Slavonic and East European Review 89, no. 1 (2011): 128-30.

93. Though these are the some of the defining features of the chernukha, other characteristics have changed over time, as the genre evolved in Russia's turbulent social and cultural transformation. The chernukha of the 1980s gained popularity as a compelling counter to the utopian nature of socialist realism. Eliot Borenstein calls the genre "the apotheosis of glasnost: the rejection of enforced optimism based on lies and an insistence on uncovering long-suppressed truths," Borenstein, Overkill, 13. The neo-chernukha of the 1990s shifted away from revealing truths to emphasizing excesses and "overkill"-a strategy that "overexposes" rather than simply reveals daily realities, ibid., 6. 
Leviathan focuses on the everyday, lived experiences of an average Russian family, and sex, violence, and swearing are integral to the film. ${ }^{94}$

What is compelling about this long narrative tradition of the "little man" is that it is always about more than just gaining a new perspective. The shift from a great hero to the everyday Russian effectively challenges romantic versions of heroism and historical agency, as the struggles and suffering of the "little man" question the heroism of great men of his or her time. The Bronze Horseman, for example, creates ambiguities about the identity of the hero and interrogates the consequences of heroic action: Evgenii's rebellion leads to his death, while Peter the Great's political ambition costs "lesser men" a world of suffering..$^{95}$ Note also that the "Bronze Horseman" is a tragic tale. ${ }^{96}$ It begs the question of whether the horseman is hero or monster. Similarly, Zvyagintsev's titular Leviathan is clearly a destroyer, rather than savior, while Kolya's tragic failure provoked audiences to think about the nature of authority and the consequences of revolt. Similar to nineteenth century "little man" texts, the chernukha tradition always referenced particular political, social, and moral realities. The revelation of the ugly details of poverty and broken families, whether "realistic" in the 1980s or "overexposed" in the 1990s, reveal uncomfortable realities and hidden connections between forms of authority and everyday existence.

The narrative tradition of the "little man" is interesting for our analysis, because the tragic fate that often befalls the "little man" allows artists to circumvent the conjuring of utopian alternatives. The hallmark of chernukha, for example, is precisely that it contrasts the socialist utopia with dystopian narratives that are intentionally devoid of stable ontological position. Chernukha films of the 1980s initially offered a sort of moral high-ground, in the sense that it presented problems Soviet authorities chose to ignore. In Seth Graham's words: “in place of the [socialist realist] pure idealism, logocentric optimist and "conflictlessness" (бесконфликтность), [chernukha] offers pure naturalism, mute pessimism and omnipresent conflict (всеконфликтность)."97 Yet at the same time, Eliot Borenstein argues, "the audience was simply presented with a bleak picture and left to draw its own conclusions." 98 After the Soviet Union disappeared as a moral anti-thesis, chernukha films of the 1990s no longer offered even implicit values or role models to audiences-instead, they focused on vivid depictions of violent, everyday struggles in and with "raw life."

94. Brigit Beumers argues that Russian film makers use obscene language and vulgar-

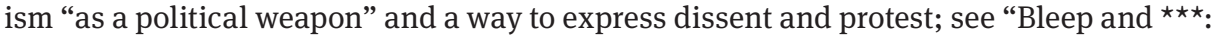
Speechless Protest" in Beumers et.al., Cultural Forms of Protest in Russia.

95. Pushkin's poem "is a 'tale' where the hero is not clear"-heroism could be read in Peter's attempt to master nature, or in Evgenii's attempt to challenge Peter, according to John Kevin Newman in "Pushkin's 'Bronze Horseman', 174-75.

96. Banerjee, "Pushkin's 'The Bronze Horseman'," 47-48, 59. Banerjee showed that Pushkin's epic poem marks a turn away from Romanticism's glorification of Peter and, instead, contributed an "authentically tragic vision" of Peter's historical legacy and the costliness of his rule.

97. Graham, "Chernukha and Russian Film," 3.

98. Borenstein, Overkill, 12. 
Leviathan borrows from the tragic element that is present in the little-man tradition and from the anti-utopian and inconclusive, pessimistic element of chernukha. ${ }^{99}$ Zvyagintsev thereby revealed the underside of Putin's Russia through the tragic tale of Kolya's fall in ways that were familiar to Russian audiences, without proposing a coherent ideational alternative that could improve the protagonists' suffering. This is evident in Zvyagintsev's treatment of the protagonist: he does not simply suggest that we should focus on Kolya either as an everyday hero who shows us solutions to Russia's problems, or as an agent of change striving to fulfill the values of his times. Kolya briefly appears heroic at the beginning of the film, challenging the state to try to save his home and family, while the authorities of the town are pathetic. Kolya is ultimately a tragic hero, however, crushed by larger forces, imprisoned following his choice to rebel.

It is this depiction of the fall of a hero in the little-man tradition that triggered social debate. Audiences were "left to draw their own conclusions" in Borenstein's formulation, and they did so, by interrogating who can be a hero and who cannot-or, in other words, whose heroism is worth the suffering, has agentic power, and whose does not. ${ }^{100}$ For some observers, it was precisely Zvyagintsev's focus on a failed, everyman hero that was the film's main flaw and provoked observations that there were no recognizable heroes in the film. Russia's Minister for Culture, Vladimir Medinsky, found the film disturbing and full of "existential hopelessness" (экзистенциальной безнадеги), precisely because of its lack of a positive hero (среди героев фильма вообще нет ни одного положительного героя). ${ }^{101}$ Vadim Polupanov, a journalist writing for the popular magazine Argumenty i Fakty responded similarly to the film: he objected to the fact that all of Leviathan's characters are defined by their vices. Leviathan's protagonists, according to Polupanov, are "false, mean, arrogant" and are shown to engage in deplorable acts: "treachery, corruption, betrayal, alcoholism." 102 In neither Medinsky's nor Polupanov's responses does Kolya register as a hero. Perhaps this is because it contradicts state-sponsored narratives, in which the president claims to personally take care of "little men" like Kolya. ${ }^{103}$ The vile and chronically-drunk authority figures in the film cannot fulfill the role of leaders and heroes. Yet, as the responses from Naval'nyi and other journalists showed, audiences familiar with Russian cultural traditions clearly recognized Kolya as a tragic "little man" hero who has played the role of revealing sociopolitical wrongs and conceits at least since Pushkin. Once

99. An interesting strand of the film's narrative is that one of the options for Kolya is to give in to authorities and move to a flat that is closer to town. This suggests familial domesticity as a value, though it is ultimately shown to be an unviable solution to Kolya's predicament.

100. Nancy Condee also argues this, in "Knowledge (Imperfective)" .

101. See Medinsky at https://iz.ru/news/581814 (last accessed September 27, 2018). Vadim Polupanov, “Звягинцев нарочито густо снабдил своих героев всеми возможными человеческими пороками-лживостью, подлостью, наглостью и далее по списку. . . . Предательство, коррупция, измена, подлость, алкоголизм . . . здесь на каждом шагу. В этом фильме нет ни одного положительного персонажа.”

102. References to corruption are highly political in contemporary Russia; this is especially evident in Naval'nyi's expositions of high officials' corruption.

103. Rutland, "The Place of Economics." 
again, Leviathan presented audiences with a challenge that triggered social debates: on the one hand, the film clearly posits a familiar, though very different hero from the one that state-sponsored narratives propose; on the other hand, the hero fails, questioning the efficacy of the heroism of the powerless.

\section{Debate 3: Authenticity-What Are "True" Russian Values?}

A third debate set in motion by Leviathan concerned the question of how Russian life and values can be authentically represented, which unfolded as a discussion on whether the film was a "truthful" reflection of Russian realities. As noted above, Zvyagintsev resisted the reception of the film as primarily a depiction of Russian life. He positioned Leviathan's plot as a "universal tale" based on an account of a man from Colorado who lost a zoning dispute with local authorities. "This story could happen anywhere," Zvyagintsev argued. ${ }^{104}$ Yet, he also said that "the country," Russia, needs the film, because it tells the "truth about today." 105 Moreover, his choice to set Leviathan in a typical, remote Russian town generated extensive debates on whether the realities in the film are authentic representations, important for our argument. Dmitry Bykov argues forcefully: "[Leviathan] is one of the first Russian movies that depicts, not fully, but clearly, an image of today's reality."106

Not surprisingly, the depiction of the Orthodox Church stirred the most vivid debates about the film's truthfulness and authenticity. The film's main religious figure, the metropolitan, is corrupt, loves earthly delights, and sides with the loathsome mayor. A more humble and altruistic cleric appears towards the end of the film, but his advice to Kolya-submission to God's authority-turns out to be impotent in alleviating his suffering. Whether this depiction of the Orthodox Church and many other features of the film (the heavy drinking, for example) were truthful or not, or authentic or not, was intensely contested. Orthodox priest Vsevolod Chaplin commented that the movie reproduces facile myths about Russia, which the filmmaker used to appeal to western audiences and jurors of film festivals. He suggested that Zvyagintsev may as well have featured bears, pickles, and balalaikasequally facile stereotypes-and found the film guilty of celebrating western values of individualism, private property, and "anti-state" views (культ индивидуализма, частной собственности, анти-государственности) at the expense of Russian values. ${ }^{107}$ Tatyana Trubilina, the head of the munici-

104. Zvyagintsev, quoted in Masha Lipman, “The Campaign Against 'Leviathan' in Russia,” New Yorker, January 26, 2015, at www.newyorker.com/news/news-desk/ campaign-leviathan-russia (last accessed September 27, 2018).

105. Zvyagintsev: “Почему фильм нужен стране? Это правда сегодняшнего дня. Это правда целительная. . . . так жить затруднительно если вообще возможно,” Sobchak Zhivyem, YouTube video, 58:17, posted by TV Rain, March 6, 2015, at https://www. youtube.com/watch?v=WRtBoFzzEfU (last accessed November 16, 2018).

106. Dmitrii Bykov: “Это первая за много лет русская картина, в которой есть пусть и неполный, но эмоционально внятный образ нынешней реальности.” See “Mimo," Novaya Gazeta, January 19, 2015, at https://www.novayagazeta.ru/ articles/2015/01/19/62686-mimo (accessed November 19, 2018).

107. Chaplin also suggested that this is a strategy that clearly worked, as the film won several prizes; see at rusnovosti.ru/posts/361271; www.interfax-religion. $\mathrm{ru} /$ ?act $=$ news\&div=57959 (last accessed September 27, 2018). Note that Chaplin's claim runs counter to our own observations, which suggest that the film succeeded in generating 
pal council of Teriberka, accused the movie of presenting a false description of the town. In her eyes, the movie was "useless, lacking truth and full of lies” (бесполезный, неправдоподобный и лживый). ${ }^{108}$ Similarly, prominent journalist and blogger Dmitry Olshansky opined that every word and scene contained "rotten, dull, onerous lies." 109 Many other prominent critics of the film (Sergey Medinsky, Gennady Zyuganov, and Sergey Markov) argued that the film was made for Russophobic, foreign audiences, that it panders to false stereotypes, and obscures Russian reality. ${ }^{110}$ Descriptions of the film as "antiRussian" (антироссийский) and unpatriotic were very commonly voiced in Russian media (Izvestia and NTV, for example), clearly drawing on nationalist rhetoric wherein any critique of Russia is either emanating from or ingratiating to a hostile west. ${ }^{111}$

Remarkably, however, there were just as many people who found the film to be a truthful reflection of Russian life as those who thought it was a misrepresentation. As noted above, many regular citizens recognized elements of the film as reflections of their experience. The Levada Center conducted a cross-regional survey, questioning randomly selected citizens on whether they had seen the film and whether they thought it "objectively portrayed Russian life." ${ }^{112}$ This suggests that authenticity was a key concern of the actors who commissioned the survey (likely the government). The responses to this survey question are notably ambiguous: among those who had seen the film,

debates because it did not explicitly uphold western values. Rather than claiming that the film did or did not unambiguously promote western values, we argue that the tragic structure of the film leaves the answers to its many questions unanswered and unresolved, with no clear panacea offered for the tragic ills presented in the film.

108. “Татьяна Трубилина считает ленту “бесполезной и неправдоподобной,,” NewsRu, January 13, 2015, at www.newsru.com/russia/13jan2015/levi.html (last accessed September 27, 2018).

109. Opinion by Dmitry Olshansky, quoted by NTV: “Какая же тухлая, вялая, тягостная ложь в каждом кадре и каждом слове,” NTV, January 13, 2015, at www.ntv. ru/novosti/1287478/ (last accessed September 27, 2018).

110. See the comment by Vadim Levental' in the prominent daily Izvestiia, who accused Zvygintsev's philosophy of obscurantism characteristic to the Middle Ages (посредневековому ... мракобесна), and called Leviathan simply a "bad" film, see "Ochen nuzhnyi i svoevremennyi fil'm,” Izvestiia, January 13, 2015, at https://iz.ru/news/581723 (last accessed September 27, 2018).

111. Opponents of the film clearly tried to use the strategies of distancing and alienation that had worked to downplay the social critique in Pussy Riot's performances: see statements by Zyuganov, Medinsky, Leventhal, Markov, Mamontov, Meskhiev. For Medinsky's statement, see "Vladimir Medinskii: 'Leviafan' zapredel'no kon"'iunkturen," Izvestiia, January 15, 2015, at https://izvestia.ru/news/581814 (last accessed September 27, 2018). For Zyuganov statement, see NTV, at www.ntv.ru/novosti/1290780/?fb\#ixzz3YtpFI RRg (last accessed September 27, 2018). For Leventhal', see Izvestiia, January 13, 2015, at https://izvestia.ru/news/581723. For Mamontov, see "Arkadii Mamontov: Esli by ne Putin, u nas bylo by strashnee, chem na Ukraine," Kul'tura, March 31, 2015, at portal-kultura. ru/articles/tv/95481-arkadiy-mamontov-esli-by-ne-putin-u-nas-bylo-by-strashnee-chemna-ukraine/ (last accessed September 27, 2018). For Meskhiev, Dmitrii Meskhiev: Nuzhno pokazyvat' raznoe," PLN, March 5, 2015, at https://pln-pskov.ru/culture/196990.html (last accessed September 27, 2018).

112. See at https://rusnovosti.ru/posts/361271 (last accessed September 28, 2018) and at www.levada.ru/07-05-2015/leviafan-vnimanie-i-otsenki (last accessed September 28, 2018). 
opinions were evenly divided as to whether they thought it was a truthful or a distorted depiction of Russian reality. This even split is remarkable-it further attests to the film's capacity to generate debate.

Perhaps the most important arguments in favor of the film as authentically Russian were frequent comments that the film carries on the torch of an indigenous narrative tradition. Vyacheslav Kostikov locates Leviathan within the literary tradition of truth-telling, characteristic of such giants as Pushkin, Mikhail Lermontov, Aleksandr Ostrovskii, Fedor Dostoevskii, Aleksandr Solzhenitsyn, and Dmitrii Likhachev. ${ }^{113}$ Vladimir Pozner compares it to the work of Solzhenitsyn and Boris Pasternak. He argues that the film clearly shows that Zvyagintsev's "heart aches for Russia," and notes that this is a sentiment that also ran through Soviet-era dissident authors' works. ${ }^{114}$ Elsewhere, he shares that he was "struck by the merciless and heavy truth" of the film. ${ }^{115}$ These commentators value the film as a work of art that has the power to expose "true" Russian realities. What is more, in these comments a distinctly Russian narrative tradition, truth-telling (revealing authentic realities) and patriotism are complements: literature and art model a type of patriotism by provoking debates about painful and objectionable, but "real" (authentic) experiences. In fact, the film explicitly invites the debate on questions of truthfulness through a powerful final scene in which the metropolitan contrasts God's truth (истина) with Man's truth (правда) during a pompous ceremony at the opening of the new church built on the ruins of Kolya's house. Our intention, again, is not to arbitrate whose truth and what reality the film depicts. Instead, the project of mapping ideology privileges the task of detailing the ways in which it prompted Russian audiences to reflect on precisely these questions: whether experiences and values reflect the "real" Russia today (the drinking, the value of friendship, the relationship between the clergy and the mayor), versus western ideas of Russia, versus universally human experiences (betrayal, suffering).

\section{Creative Spaces, Cultural Production, and Civil Society in Russia}

Zvyagintsev's Leviathan was exceptional in that it managed to exploit vulnerabilities in the state's narratives of the post-1990s political contract. The film portrayed the Russian state itself as the source of instability that threatens its own citizens, offering an essentially tragic and inconclusive narrative that disrupted claims central to romantic, state-sponsored narratives. It thereby

113. Full quote by Kostikov in Argumenty i Fakty: “О губительности лжи для народа, власти и в конечном счёте для страны писали Пушкин, Лермонтов, Островский, Достоевский, Толстой, а в советские времена Солженицын, Лихачёв, писателидеревенщики. И во все времена-русские философы и мыслители,” See Argumenty i Fakty, March 18, 2015, 12, at www.aif.ru/society/opinion/1468743 (last accessed September 28, 2018).

114. See Radio Ekho Moskvi, January 24, 2015, at https://echo.msk.ru/blog/ pozner/1480220-echo/ (last accessed September 28, 2018).

115. See at https://pozneronline.ru/2015/01/10158/ (last accessed September 28, 2018): “Но более всего правдой, беспощадной, тяжелейшей правдой.” 
generated critical debate on at least three exceptionally political and provocative questions-on authority, on agency, and on authentic Russian realities and values. The Leviathan debates merit attention, because they can be seen as taking part in a state-society dialogue that constitutes Russia's postSoviet ideological terrain, offering a contrast to both top-down and bottom-up accounts of ideology.

An analysis of the content of these debates also bridges the gap between studies of ideology and post-Soviet civil society. James Scott has noted that approaching ideology and political life in this way-as non-saturated by hegemonic, elite discourse and involving "low-profile" forms of response and resistance to these discourses-is useful for social scientists, because we are not "reduced to waiting for open social protest [as empirical proof of resistance or contestation ... ]." 116 The unresolved, unfinalized narrative of Zvyagintsev's Leviathan proved to be a valuable site for such contestation. The film offered no concrete solutions and no guiding morals, no new utopia, nor clearly defined "outside-in" values. Instead, it created a space to formulate questions and alternatives to the narrative that legitimizes Putin's era. This space-and others created by similar artistic interventions-warrant the attention of scholars of post-Soviet politics. 